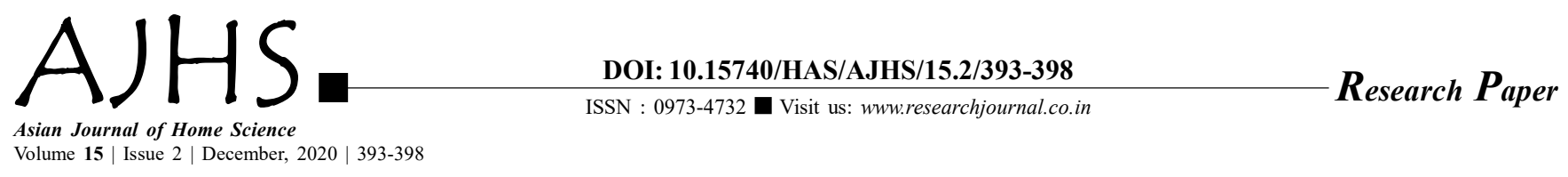

\title{
Attitude of men and women towards use of mobile phone
}

\author{
Geeta Channal, Rekha Rayangoudar and Supriya Patil
}

Received: 09.10.2020; Revised: 09.11.2020; Accepted: 27.11.2020

See end of the paper for authors' affiliations

\section{Geeta Channal}

All India Co-ordinated Research Project-Home Science Extension, University of Agricultural

Sciences, Dharwad (Karnataka) India

Email : geetrajpatil@yahoo.co.in
ABSTRACT : Information and Communication Technology (ICT) is a tool which benefits all spectrums of people in the world and reach millions of people every day. Recent developments in the fields of information and communication technology are undeniably revolutionary in nature. Information has become the principal determinant of the progress of nations, communities and individual. There is a potential for ICTs to purge gender discrimination and to empower women in society. But with science, technological innovations and socio-economic changes, women, even rural women, are progressively starting to utilize various kinds of technological instruments. ICTs perform as an agent to empower women, allowing them into the main torrent of society. Amongst the various kinds of ICTs the cell/ mobile phone has reached a significant place. This technology provides knowledge, social security, social networks and self confidence to rural people, An attempt has been made in this paper to explore the attitude of farmers and farm women towards the use of ICTs. This study was conducted in Sulla village of Dharwad district with a sample of 100 farmers and 100 farm women. Pre tested interview schedule was used for data collection and suitable statistical tools like frequency, percentage, means, standard deviation and t-test were used for analysis of the data. The study revealed that, more number of respondents belonged to young age, educated up to middle school, they were married, from joint families and farming was the main occupation of the respondents. The $\mathrm{Z}$ test revealed that there was a highly significant difference between the attitude of men and women towards use of ICTs. The analysis further revealed that, almost equal per cent of men $(45.00 \%)$ and women $(46.00 \%)$ belonged to low category of attitude followed by high category in men $(29.00 \%)$ and medium category in women $(32 \%)$.

KEY WORDS: ICT (Information \& Communication Technology), Attitude, Availability, Accessibility, SMS

- HOW TO CITE THIS PAPER : Channal, Geeta, Rayangoudar, Rekha and Patil, Supriya (2020). Attitude of men and women towards use of mobile phone. Asian J. Home Sci., 15 (2) : 393-398, DOI: 10.15740/HAS/AJHS/15.2/393-398. Copyright@ 2020: Hind Agri-Horticultural Society. 